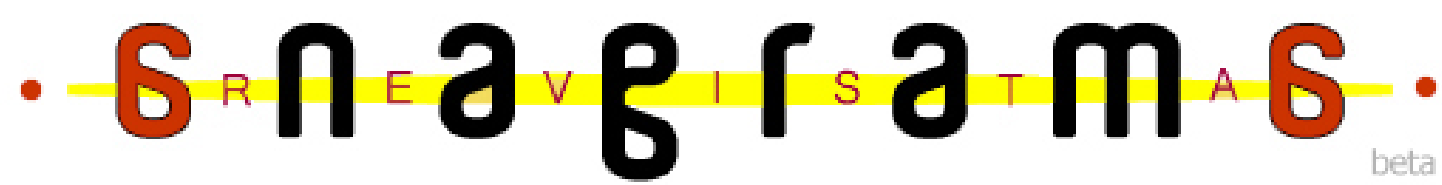

\section{De Espelhos e de marcas: a literatura de não-ficção ${ }^{1}$}

\section{Luis חakajo?}

\section{Resumo}

O presente ensaio analisa os processos epistemológicos que perpassam a narrativa de nãoficção, partindo da enganosa metáfora de "espelho da realidade", articulando os conceitos de intelecto, conversação e leitura birreferencial, e colocando a obra de Tom Wolfe, na parte final, em perspectiva.

Palauras-chaue: Jornalismo Literário; Não-ficção; Discurso; Reportagem; Novo Jornalismo; Texto.

"Embora nenhum empenho possa recriar o universo em um modelo, nem pela melhor acumulação ou disposição de detalhes, o mundo ainda assim reaparece em miniatura em cada evento, de forma que todas as leis da natureza podem ser lidas no menor dos fatos. O intelecto precisa ter a mesma perfeição naquilo que apreende e naquilo que produz". Ralph Waldo Emmerson. Intelecto ${ }^{3}$.

\section{OEspelho}

Uma das metáforas mais utilizadas para caracterizar a narrativa não-ficcional é a de “espelho da realidade”. Ela é extremamente inadequada. Sua natureza, feita e simbólica, não é análoga à da reflexão em pedras polidas ou na superfície da água parada. $\mathrm{O}$ artefato literário (ou seja, aquele composto de palavras) é uma sucessão de camadas (Candido, 1968), diferentemente do espelho, sobre e a partir das quais operam a semiose e a atribuição de significados, em cuja realização sujeito e objeto, leitor e autor vêm à luz num mesmo momento.

\footnotetext{
${ }^{1}$ Artigo desenvolvido a partir de "Através do espelho", projeto de iniciação científica desenvolvido, entre setembro de 2007 a agosto de 2008, com bolsa da Fundação de Amparo à Pesquisa do Estado de São Paulo (FAPESP).

${ }^{2}$ Luis Nakajo é aluno do sexto semestre do curso de Comunicação Social - Jornalismo da Escola de Comunicações e Artes da USP.

${ }^{3}$ EMMERSON, Ralph Waldo. "Intelecto” in Ensaios: Primeira Série. Rio de Janeiro: Imago, 1994.
} 
De acordo com Umberto Eco (1989: 25), a imagem do espelho não é um signo porque depende do objeto refletido e do medium em que ganha forma: tira-se o objeto da frente do espelho e sua imagem some. No espelho vale uma relação entre ocorrências. No signo, entre classes gerais. "O signo não é dado pelo fato de que esta fumaça me remeta àquele fogo: a classe geral das ocorrências reconhecíveis como fumaça remete à classe geral das ocorrências definíveis como fogo”, exemplifica ele.

A metáfora da especulação nos serve, ironicamente, apenas quando invertidas as posições: lemos o que o espelho configura em sua superfície e, numa inversão baseada no "preconceito cartesiano" (Eco, op. cit.), projetamos fora dele as imagens de sua superfície.

No longa O Ilusionista (Neil Burger, 2006), é ilustrativa a cena em que a mocinha encara o espelho e nele vê uma figura encapuzada que ataca, com uma espada, seu reflexo juvenil no espelho. Ela se apalpa, temerosa de que seu corpinho tenha sido realmente perfurado. Seu reflexo, em seguida, cai ao chão e morre. Ela, a mocinha, continua viva e em pé, aliviada, encarando seu reflexo prostrado sobre o tablado refletido. Por sua vez, em Lisbela e o prisioneiro (Guel Arraes, 2003), a personagem de Selton Mello explica à de Débora Falabela como tais truques de espelho (no caso, a transformação de uma mulher num orangotango) são manufaturados por um intrincado jogo de espelhos, que brincam com nossa cegueira cartesiana.

\section{Leitura Birreferencial}

A situação acima se dá pelo único caráter que a narrativa divide com o espelho de Eco: ela é uma "prótese", aumenta o raio de ação de um órgão. No caso específico, esta extensão é operada na compreensão de elementos do mundo de comum referência (outro termo emprestado de Eco, 2004). Em outras palavras, o texto nos projeta numa relação de conversação (Flusser, 1963, cf. 4) com o mundo em que estamos imersos.

Na figura 1, podemos observar como o "leitor máximo" (Piglia, 2006) Jorge Luis Borges, numa situação hipotética, admira a obra do italiano Umberto Eco. Quando esquematiza em narrativa a realidade que apreende, o autor se inscreve como narrador. 


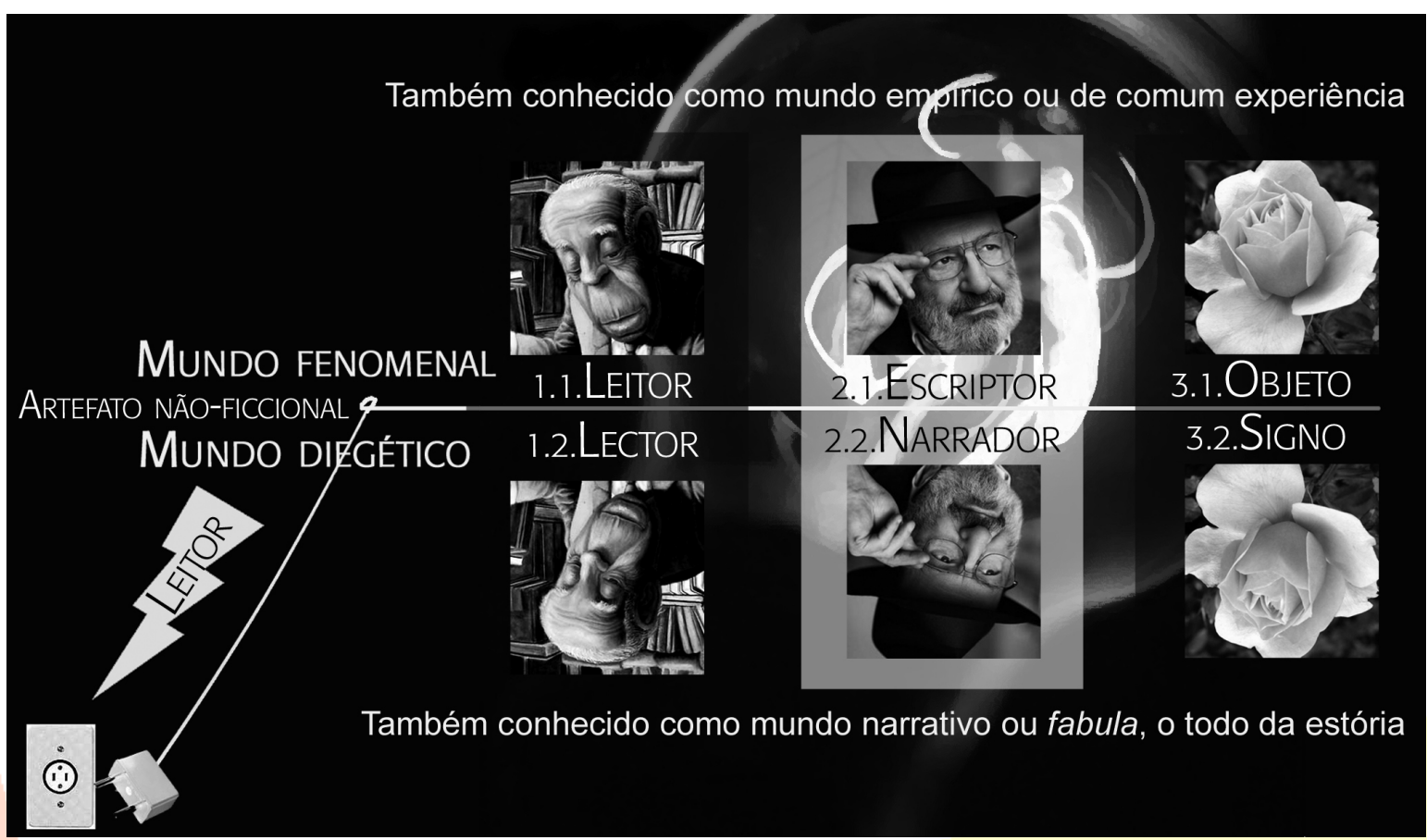

Figura 1: As personas envolvidas na realização do artefato não-ficcional

$\mathrm{O}$ artefato não-ficcional, assim, evidencia a intimidade entre dois mundos, de entendimento igualmente sujeito-dependente, mas a que damos importância e experimentamos diversamente: o mundo fenomenal (1) e o mundo narrativo (2). Este é a fabula de que fala Todorov (1977: 42-3): é "matéria básica da estória, a soma dos eventos narrados", organizados pelo narrador (2.2) em trama, plot, "a história como é contada ou o modo como os eventos estão ligados uns aos outros". Nesta figura, o leitor, no papel de lector (1.2), alimenta a máquina narrativa e as projeções em sua experiência. Ele leva consigo os referenciais do mundo fenomenal, leva sua biblioteca, ao entrar no texto. E tira do texto "figuras", não necessariamente visuais, de sua leitura.

Atualiza o texto de forma a ler, através do narrador, a figura abstrata de um escriptor; Mas não lê uma pessoa, lê um caráter: "sub specie aeternitatis, não o indivíduo (...), único e insondável (...), mas, (...) o tipo genérico (...), que é obra do esquecimento e da memória" (Borges: 2008, 44). Lemos um e, em vários momentos, achamos que lemos o outro. 


\section{0 Intelecto}

Artefatos não-ficcionais são sintetizados por indivíduos que, no ato da escrita, expelem suas apreensões de forma a dialogar com o que os cerca - e com os indivíduos que formam sua comunidade de convívio (Maturana, 1997). Esta comunidade se forma sempre num apreender-expelir, num acoplamento em que nada externo determina os significados internos aos indivíduos. Pelo menos aos indivíduos que importam: aqueles que se constituem como intelectos. Quando apenas reverberamos conceitos vazios de significado (porque vazios de pensar), ficamos na “conversa fiada" (Flusser, 1963), na emissão de ecos desarticulados.

Quando imerso no mundo, o homem se vê organizando fenômenos. Ele experimenta a realidade e se entende através de estímulos deste mundo, externo a si, mas que ganha existência através de um "salto primordial ontológico" (Flusser, op. cit.: 34) entre o dado bruto (os númena) e as palavras (que, para Flusser, se confundem com os fenômenos apreensíveis pelo intelecto).

Para Schopenhauer, este é o salto entre o "mundo como vontade" e o "mundo como representação"; para Nietszche, entre a "vontade" e o "poder"; para Bergson, entre o "élan vital" e o intelectualizar-se; e para Heidegger, entre o "Vorhandensein" (estar adiante à mão) e a transformação em "Dasein" (existência). Quando se debruça sobre o que não pode alcançar, o dado bruto, o intelecto se dirige ao pensamento "mais difícil (ou pesado)", na concepção nietzschiana, "um peso que o intelecto não suporta" (Flusser, 1963: 35).

Este abismo entre o que a língua gera em fenômenos, e que é tudo o que podemos apreender; e o que desejamos ingenuamente que esta língua exprima - os tais "dados brutos" - é a condição de existência do homem enquanto ser cognoscente.

Edgar Morin identifica nessa inacessibilidade do homem ao mundo-em-si (númeno) um imperativo para conhecer o conhecimento. A percepção humana é uma percepção organizadora. Sem organizar o que apreende, simplesmente não conhecemos. O ser cognoscente, de acordo com Morin, apreende apenas os fenômenos, porque, para ele, só há fenômenos a apreender, nada mais. Fora disso, apenas intui um abismo caótico, lamaçal de onde o cérebro e o espírito retiram ocorrências no processo mesmo de interagir com o que cerca seu organismo. 
No terceiro volume de seu Método (1999), Morin descreve longamente os processos bioquímicos que baseiam o cômputo ("computação de si, a partir de si, em função de si, para si e em si” [58]) do cérebro humano. A partir desta dança de hormônios e acoplamento de células, geramos uma projeção, pensamos, cogitamos.

[A computação cerebral] produz representações que, na percepção, projetam-se sobre o mundo exterior e identificam-se à realidade percebida. Ressuscitada por e na rememoração, a representação reconstitui, apesar da sua ausência, a presença concreta dos seres, coisas e situações evocadas (188).

Para completar seu circuito, a teoria do conhecimento de Morin leva em conta o conhecimento sobre o cognoscente e seu processo cognitivo, para estabelecer até que ponto nosso conhecimento sobre o mundo é um conhecimento válido. Assim, "a computação viva permite-nos conceber a emergência simultânea, inseparável e distinta do sujeito e do objeto" (256, grifo nosso).

Desta maneira, Morin, como ele próprio afirma, vai além do realismo ingênuo; além do "realismo crítico" (cujo maior representante é Karl Popper); vai além do idealismo clássico (de linhagem platônica); e além do criticismo kantiano (que ignora, de acordo com Morin, que [o espírito] foi co-produzido pelo mundo" [260], numa relação de filogenia e evolução).

Morin defende um realismo relacional, porque considera "indestrutível [a] relação sujeito/objeto e espírito/mundo"; relativo, porque destaca a "relatividade dos meios de conhecimento e [a] relatividade da realidade cognoscível”; e múltiplo, porque diz respeito “à multiplicidade dos níveis da realidade e, talvez, à multiplicidade das realidades".

Segundo esse realismo relativo, relacional e múltiplo, o mundo fenomenal é real, mas relativamente real, e devemos mesmo relativizar nossa noção de realidade admitindo uma irrealidade interna a ela. Esse realismo reconhece os limites do cognoscível e sabe que o mistério do real não se esgota de forma alguma no conhecimento (270).

O númeno é maior que o cognoscível, porque conhecemos apenas o mundo fenomenal, ready-made, em que já se operou a seleção e ignorância de estímulos que a computação, em sua dinâmica, exclui. Para conhecer, é preciso

não apenas codificar, mas também imaginalizar e abstrair [...]; o real deve necessariamente, para ser conhecido, irrealizar-se em signos/símbolos, representações, discursos, idéias. É pela sua irrealidade que o conhecimento tem acesso à realidade, mas essa irrealidade deve 
organizar-se e é através dessa organização "real" que o conhecimento entra em correspondência com a realidade" (260, grifo nosso).

Essa analogia entre estruturas é o que também enxergamos na constatação de Emmerson, encontrada como epígrafe deste ensaio. A irrealização simbólica implica num conceito de conhecimento "como adequação de uma organização cognitiva (representação, idéia, enunciado, discurso, teoria) a uma situação ou organização fenomenal" (268). São dois textos, os dois internos ao sujeito, sintetizados em sua relação com o mundo - a representação e o fenômeno são configurados igualmente em nossa experiência.

A adequação deste conhecimento não é realizada por um reflexo do mundo cognoscível, do mundo fenomenal que tanto angustiava o pintor francês Cézanne, e nem mesmo pela cópia deste, mas sim pela simulação. Uma "re-produção mental" nos modos analógico (pela via da representação) e homológico (pela via da teoria).

A representação, reconstituição concreta, singular do fenômeno, e a teoria, reconstituição abstrata e generalizante, funcionam como modos de adequação do aparelho cognitivo ao fenômeno. Assim,

\begin{abstract}
a correspondência cognitiva que se estabelece [...] pode ser considerada como uma espécie de ressonância entre o cognoscente, o conhecimento e o cognoscível, inclusive no conhecimento teórico. Como sugere Jean Ladrière, 'a correspondência entre o órganon conceitual da teoria e o real não é a mesma que liga um quadro ao seu objeto, mas a que liga dois dispositivos oscilatórios ocasionalmente muito diferentes, cujo periodo de vibração seria o mesmo (269, grifo nosso).
\end{abstract}

Daí, Morin infere que "em nenhum caso, o conhecimento esgotaria o fenômeno a ser conhecido e a verdade total, exaustiva e radical é impossível. Toda pretensão à totalidade ou ao fundamento resulta em não-verdade".

\title{
3. Conversação
}

O conhecer ativo, portanto, é de fundamental importância para a síntese e atualização do conhecimento. O que se conversa pode ser refutado, pode ser aceito por uma ampla comunidade - e refutado por outra. A realidade é um acordo social.

No caso das visões religiosas e explicações sobrenaturais para a vida terrestre, Richard Dawkins (2006) vê mera cock and bull story. Partindo de sua experiência de cientista, Dawkins desmancha, com base em parâmetros racionais, os pilares do 
pensamento religioso - a maioria dos quais incluem autênticas bullshits (Frankfurt, 2005, cf. 5) como a crença de que pessoas não-religiosas são mais propensas à perversidade.

Para a comunidade científica, as explicações religiosas são nulas, débeis, contraditórias. Para as mentes que se encontram engajadas nestas explicações, são explicações válidas. A maioria dessas mentes se encontra no estágio da conversa fiada (Flusser, 1963, cf. 5), em que repetem $x$, quais papagaios, sem um pingo de senso crítico ou dúvida (que a religião ortodoxa execra, por motivos óbvios). Há, porém, como identificado por Dawkins, uma classe de religiosos de mente "sofisticada", os quais não acreditam que a Terra tem apenas 5 mil anos ou que o genocídio é válido na conquista de Canaã porque a Bíblia assim o diz, verbatim (a ausência de humor e ironia na exegese bíblica é muito bem explicada por George Minois, 2003, cap. 3).

A conversação seria a camada da língua em que verdadeiros intelectos se engajam na leitura do cognoscível, co-criando a realidade ativamente, com os elementos produzidos do nada, pelo poietés (ou pelo profeta), "pontas de cunha que a conversação força para dentro do indizível” (165). A poesia é, assim, num amplo sentido, a camada da invenção, do original, gerando conhecimento novo,

progressos no conhecimento da ordem (determinações e determinismos), da desordem (princípios e regras de ligação, de reunião, de agenciamento), assim como os progressos na aquisição e na organização das informações (Morin, 1999: 267).

Da camada poética da língua, esta língua criada ex nihilo, "desce para a camada da conversação, para ser diluída, a fim de ser apreendida e compreendida. Assim, a conversação não passa de uma crítica elucidativa, embora inconsciente, da poesia" (163, grifo nosso).

Esta posição é muito semelhante à de Humberto Maturana (1997: 175), cujos ensaios de Ontologia da realidade propõem que "o humano se vive sempre num conversar", assim como consideram o amor a "emoção que funda a origem do humano".

O conversar, desta maneira, resulta da necessidade humana a viver junto, "na aceitação do outro junto a nós, ou seja, no amor, que é a emoção que constitui o espaço de ações no qual aceitamos o outro na proximidade da convivência" (175). Esta aceitação do outro é a base do que Maturana denomina "objetividade entre parênteses" (266), que se contrapõe à objetividade positivista. A última se caracteriza pelo fechamento do conversar, pela procura de um "argumento coercitivo" (a "realidade objetiva", externa) que têm 
validade explicativa e universal, independente de sujeitos (observadores) e que, caso não aceito, caracteriza discordâncias como sustentadas por argumento "arbitrário, ilógico ou absurdo" (244).

Em constante atualização, este real conversável é expandido pela ação de atividades criativas, poéticas ${ }^{4}$. Nas ciências, a busca pela apreensão da verdade e o expelir de teorias que expliquem genericamente vários acontecimentos encontra um ponto interessante no racionalismo crítico de Karl Popper. Ele dá mais valor à crítica (em outras palavras, à conversação) do que as declarações de verdade, o conhecimento ossificado.

De acordo com Alvaro Ferreira (2002: 57),

Se o mundo existe, existe uma verdade absoluta. Ela seria a verdade da total apreensão do mundo (...) nossa mente tenta apreender o mundo, mas é inapta nessa tarefa. Nossa tentativa de apreensão do mundo é sempre parcial. Sempre impregnada de erro (...) o que não quer dizer que devamos abandonar a idéia de que essa verdade existe. ${ }^{5}$

Longe de apenas relegar a inteligência humana a uma posição humilde, de imperfeição, esta constatação, de acordo com Morin (1999: 26), só torna mais imperiosa a pesquisa do processo de conhecimento, pois, pergunta-se ele, "saber que o conhecimento não possui um fundamento não é ter adquirido um primeiro conhecimento fundamental?". Ciro Marcondes Filho faz pergunta retórica igualmente pertinente: "Não há como permanecer no vale-tudo (...) do pragmatismo, na desconexão do texto de qualquer outra vinculação (...). Se não é por isso, por que motivo, afinal, continuamos a pesquisar, a fazer ciência, a estudar?” (2004: 337).

\section{A Ameaça da Conuersa Fiada}

O Jornalismo, assim como a Ciência, de acordo com Gaye Tuchman (1980), é uma forma de organização do conhecimento, de experiências sociais. A notícia opera com frames, através dos quais significados (principalmente de relevância) são atribuídos a determinados aspectos focados da "realidade cotidiana". "The news frame is part and parcel of everyday reality, for (...) the public character of news is an essential feature of

\footnotetext{
${ }_{5}^{4}$ Do grego poietés, aquele que produz algo.

${ }^{5}$ A noção de verdadeiro e falso é "a novidade pioneira da linguagem humana", de acordo com Popper. Ela se articula através da crítica a "proposições descritivas (...) que descrevem um estado de coisas objetivo, que pode ou não corresponder aos fatos". Para Morin, a binaridade da organização do conhecimento humano é uma necessidade.
} 
news" (op. cit., 193). Mas a ideologia dos donos de empresas (a das relações sociais operadas no capitalismo) é incorporada ao newsmaking, prática organizacional, fechada em si, mas não desprovida de seu vínculo com pessoas comuns, usadas muitas vezes como fontes.

Ferreira (2002: 54) afirma que "assim como a ciência, o jornalismo parte do senso comum para chegar a uma aproximação da verdade. Ele parte de uma pauta, que tenta apresentar uma síntese da verdade”. O criticismo que Popper articulou no seio da dinâmica científica se baseia na leitura ativa de afirmações, a partir da qual são encontrados erros e sugeridos aprimoramentos, através de novas asserções. Geralmente, porém, esta conversação é restrita ao círculo científico, por sua linguagem carregada de tecnicismos particulares.

No caso do Jornalismo cotidiano, em que o senso comum predomina e os termos herméticos são banidos, a abertura crítica de Popper se faria idealmente, de acordo com Ferreira, com os leitores todos, que passariam a entender o Jornalismo não como um definidor de verdades, mas sim como "uma busca da verdade admitindo que seus enunciados (...) são sempre de caráter conjetural. São igualmente tentativas de se chegar cada vez mais próximo da verdade" (op. cit.: 37). Ferreira também destaca a importância da autocrítica do repórter, mas deseja, acima de tudo, que erros sejam reconhecidos e incorporados à narrativa do jornal, o que acontece quando cartas de leitores são publicadas.

O debate que Popper prezava se desenrola, dentro de sua teoria, dentro do terceiro dos três mundos que ele propõe como componentes da realidade humana. O mundo 1 é o material, "universo dos estados físicos", e inclui também as ferramentas. O mundo 2 é o mental, "mundo (...) da consciência e de todo tipo de conhecimento subjetivo", e inclui memória e imaginação. O mundo 3, de importância extrema, é o mundo cultural, "o mundo dos produtos da mente humana", o "mundo das teorias, da ciência, da arte, de todo tipo de manifestação intelectual" (Ferreira, 2002: 41).

O mundo 3 contém entidades materiais e imateriais, como "o livro e seu conteúdo". Quando produz, o homem externaliza sua subjetividade, objetifica seu conhecimento, torna-o acessível a terceiros - torna a comunicação e a conversação possíveis, ao ofertar ao outro uma superfície marcada.

Se para Ferreira "cada novo indivíduo adquire um pouco mais de vantagem na corrida pela sobrevivência”, para Harold Bloom (2002), cada novo indivíduo se angustia 
um pouco mais ao escrever após os grandes poietés da Literatura. A solução, que é a de Flusser também, é a conversação: apropriação criativa de elementos diversos em vez de "pastiche involuntário".

Este pastiche é realizado claramente na camada da conversa simples, que Flusser (op. cit.) denomina "conversa fiada". Esta camada, bem mais dilapidada, "é composta de detritos de conversação que penetram imperceptivelmente, qual o detrito de plankton (sic) no mar, em camadas inferiores" (153).

Neste processo, "frases formuladas por intelectos participando da conversação são apanhadas por pseudo-intelectos participando da conversa, sem jamais serem inteiramente apreendidos e compreendidos" (154). Sem a apreensão completa do que rola no mundo 3, estes intelectos repetem afobados o que se conversa sem nenhuma crítica ou entendimento ativo. Assim, por não constituírem um intelecto verdadeiro, por funcionarem como "papagaios", estabelecem "conversações frustradas (...) [s]implesmente refletem essas informações mecanicamente, como se fossem bolas de bilhar" (154).

O perigo de cair na conversa fiada é constante. Quanto mais imersos em sua mediocridade, menos realizados são os intelectos, e mais determinados eles são. Opera-se, destarte, numa linguagem inautêntica, numa realidade fictícia, porque não elaborada. Incisivamente como a merda de que fala Harry Frankfurt:

A palavra merda com certeza sugere [um produto sujo e grosseiro]. $\mathrm{O}$ excremento não é de modo algum projetado ou elaborado; é apenas emitido ou descarregado. Pode ter uma forma mais ou menos coesa ou não, mas não é decerto trabalhado (2005: 27, grifo do autor).

Os intelectos realizados, ao contrário, são "abertos uns anos outros, são reais (...) por estarem juntos (Mitsein apud Flusser, 1963: 151-2). Os intelectos "aprendem e compreendem, e emitem informações novas, isto é, articulam" (152). Ao tomar a informação como coisa, transformam-na em instrumento - e assim, adquirem liberdade.

Flusser diz que "as regiões além da poesia simplesmente não existem, são irreais por não serem conversáveis" (179, grifo nosso). Aquilo que não se pode conversar é irreal - está além de nossa capacidade de criação e leitura crítica em sociedade. Para Flusser, tanto os seres imaginários das lendas quanto o estar de uma mesa numa sala são reais, porque conversáveis, podem ser postos sob o crivo da causalidade e outras categorias 
lingüísticas como tempo e atividade, que, à cultura ocidental, servem de critério na definição de categorias como "fatos" e "ilusão", "sonho" e "alucinação".

\section{Leitura Atiua e Leitor-modelo da não-Ficção}

Em seu Lector in Fabula (2004), Umberto Eco propõe um modelo que vem complementar a tese de Roland Barthes sobre o prazer da fruição do texto. Este prazer, para Eco, resulta da ação do leitor na determinação dos significados, que a obra possibilita através de um processo de abertura (Eco, 2003).

Segundo Eco, a obra de $\operatorname{arte}^{6}$ é aberta - sua mensagem é plurívoca, por conta de um acréscimo de informação resultante da desordem inserida no código (109). A obra inexiste (não é realizada) sem a ação atualizadora de uma figura de leitor, presença implícita quando se escreve um texto.

Sem esse "segundo observador" (Resende, 2002), a obra permanece no virtual, no que Rosenfeld (1987) chama aspecto linear do texto, sua interface impressa, sem significado porque não há ninguém em que ser gerado. Os textos narrativos, que são especialmente visados por Eco em sua análise, são "máquinas preguiçosas", com espaços em branco que o leitor preenche com seus conhecimentos do mundo -sua "enciclopédia", o feixe, "pluralidade de textos" (Barthes apud Resende, 2002: 102) que somos todos nós.

É, na verdade, essa a condição de toda e qualquer comunicação humana, baseada na semiose ilimitada de Peirce. Se a cooperação leitor-autor falha, o leitor não entende o texto - o texto se torna ilegível ou é lido num fluir estancado. Interação destrutiva de ondas. O leitor-modelo é, no momento da escrita, o fantasma que paira inconscientemente, na mente do escriptor: geralmente ele escreve para ser entendido, escreve com elementos que não apenas ele conhece (frames), para que ocorra uma comunicação efetiva. Em síntese, o Leitor-Modelo é a inteligência última de que o texto precisa para gerar significado e imagens mentais. Conhecimento. Rememoração. Despertar.

No Novo Jornalismo de Tom Wolfe, em que a narrativa se desenrola sob os pontos de vista das personagens, recorrendo até a audaciosos fluxos de consciência, este leitor-

\footnotetext{
${ }^{6}$ Para Eco (2003), "o estímulo estético aparece de tal modo estruturado que, diante dele, o receptor não pode executar a simples operação que lhe é permitida por qualquer comunicação de uso puramente referencial: dividir os componentes da expressão para individuar seu referente singular. No estímulo, o receptor não pode isolar um significante para relacioná-lo univocamente com seu significado denotativo: deve colher o denotatum global" (84), "isso faz com que o significado seja multiforme e não unívoco" (85).
} 
modelo, sugere Fernando Resende, é um "leitor no entre", da palavra em dobra, que comporta a ambigüidade e que suporta o desmonte do real aparente (a conversa fiada de Flusser), ao se estabelecer sempre "um passo atrás da verdade". Um leitor-modelo que lê, mas não opera com a incredulidade inteiramente suspensa.

Este posicionamento aberto à conversação do leitor ante o texto, porém, é diferente do posicionamento do próprio Tom Wolfe, de acordo com Daniel Lehman e ao contrário do que faz crer Fernando Resende. Wolfe, em várias de suas entrevistas, afirmou que lidava com o factual, com o Objetivo, a despeito de todas as suas firulas estéticas e intromissões psicológicas (como diria Lillian Ross). Para ele, "a única coisa nova neste Novo Jornalismo de que falo são as novas técnicas que os escritores de não-fícção descobriram que podem usar"7. O Novo Jornalismo, para o seu representante mais histriônico, desta maneira, permanece restrito a um melhor manejo da língua (realismo formal) e aos efeitos textuais. Wolfe não vê no Novo Jornalismo uma reordenação epistemológica nas relações de leitura e foge da discussão dos desdobramentos desta prática. Não é o que acontece, porém, com uma linha que se opõe a esta omissão wolfiana. Daniel Lehman (1998) destaca alguns de seus componentes.

Dentre eles, ele cita Nat Hentoff, que em seu ensaio "Behold the New Journalism it's coming after you!", considera o movimento da década de 60 uma forma de crítica direta à criação e venda da informação na sociedade americana, centralizada nas mãos de um punhado de editores.

Ao derrubar as barreiras entre repórter, leitor e história, o Novo Jornalismo "desvela o segredinho sujo do jornalismo" (apud Lehman, 1998: 88), ao mostrar que, na composição dessas narrativas, o elemento subjetivo é inextricável. Elimina-se, assim, o que Hentoff chama de "observador anotante e sem rosto" [faceless note taking onlooker].

A crítica dirigida à ilusão da reportagem objetiva, ademais, é uma crítica ao poder de controle social e político que parte do discurso objetivo. Na década de 60 , que Resende denomina "década do desbunde", a contestação deste poder é feita com o objetivo de pulverizar o controle tirano do jornalismo, visto como instituição centralizadora. Este exercício de dominação é posto abaixo pelos participatory journalists, termo cunhado por outro jornalista da linha engajada, Jack Newfield.

\footnotetext{
${ }^{7}$ Em entrevista a Joe David Bellamy.
} 
Em seu artigo “Journalism: old, new, and corporate", Newfield afirma que a crítica [gripe] ao jornalismo não se restringe a esta indústria monopolizada, ou ao aspecto cerceante da criatividade de seus profissionais ou ao conservadorismo hipócrita (mascarado sob a "objetividade" que arrogam defender), mas, acima de tudo pelo fato de que é a própria imprensa que censura a si mesma.

Entre os valores [que orientam esta censura] estão a fé no capitalismo, em Deus, no puritanismo, na Lei, na família, na propriedade [privada], no sistema bipartidário, e -talvez o pior de todos- a crença de que a violência só é defensável quando perpetrada pelo Estado. Não posso pensar em um correspondente na Casa Branca que não compartilhe destes valores (apud Lehman, 1998: 83, grifo nosso).

Numa colocação que reflete a corrente circunstancial, Thomas R. Kendrick retoma curiosamente a posição do próprio Wolfe (a de que o Novo Jornalismo era atrativo aos leitores), e ignora a posição de Newfield e Hentoff. O discurso novo jornalístico de Tom Wolfe é absorvido pelas publicações da imprensa monopolista - e a justificativa, algo cínica, de Kendrick, é a de que "não há nada de errado em explorar a autoridade factual do jornalismo (...) e não há razão para que muita informação não seja dada de maneira recreativa [entertainingly] se os jornais querem sobreviver" (apud Lehman, 1998: 85). Não é isto, porém, o que entendemos ao ler o livro de Resende, cujas idéias sobre o processo de leitura, porém, são bastante acuradas e detalhadas a seguir.

É ao leitor do Novo Jornalismo que Resende, assim como Lehman, dá destaque na constituição da não-ficção não enquanto discurso, mas enquanto experiência de leitura, reescritura do texto. Em Resende, o leitor-modelo pressuposto pelo Novo Jornalismo wolfiano "se coloca na fronteira, em busca do devaneio, no lugar que não se faz nem no fato, nem na ficção, mas no ato de transitar entre um e outro" (Resende, 2002: 110). Ele se pergunta, constantemente, “onde estou?", “em que texto estou?”, “o texto factual ou ficcional?" (2002: 112).

Ao considerar um texto fronteiriço pelo olhar desses leitores que se fazem críticos, quais marcas levariam a pensá-lo jornalístico e/ou literário? (...) dessa maneira é que se pode cruzar os dois discursos, não a partir do que eles propõem, mas do que deles deriva, do que deles se (re)faz (Resende, 2002: 95).

"É, portanto, sob esta perspectiva que consideramos que a atualização do texto de Wolfe requer, por parte do leitor, uma indagação acerca do factual e do ficcional" (104). O Leitor-Modelo lê dois textos, um que ele considera factual e outro que ele considera 
ficcional. Dirige seu raio inteligente para um e outro e, às vezes, aos dois. Desta dialética e desta posição algo desconfortável - ele extrai a experiência de aprofundamento, implicação e diálogo com a realidade. O Leitor-Modelo da não-ficção configura um ir-evir entre o texto e o que há além dele; entre a experiência do leitor e o texto no qual ele ou ela se encontra (como indicado por Derrida).

Resende enxerga dois pactos no texto de Wolfe: um ficcional e outro factual. O último, de acordo com Umberto Eco, envolve a confiança do leitor na declaração do texto. "Uma vez postulado pelo discurso da mídia, [o submarino na praia] estava ali, e, como compete aos jornais dizer a verdade sobre o mundo real, as pessoas se esforçam ao máximo para avistar o submarino" (100). Configuram um texto factual com base em um texto que é, a rigor, ficcional. Com base na confiança e no ritual de leitura do jornal. Efetivamente, o jornalismo não lida com “fatos comprováveis”. De acordo com Dulcília Buitoni,

alguns autores falam que (...) o público pode conferir o narrado. Todavia, essa verificabilidade é mais potência que ato, pois dificilmente o receptor tem meios de chegar à notícia. Existe uma certa possibilidade de verificar se o fato foi assim mesmo (...); porém, apesar da realidade manifesta, o relato sempre tem contornos ficcionais (apud Resende, 2002: 57)

É algo muito próximo da artificialidade textual de que fala Barthes.

O leitor-modelo da não-ficção, assim, seria um leitor que Bertrand Russell, de acordo com Jorge Luis Borges, queria formar a todo custo. Ele defende uma educação contra os simulacros.

[Russell] propõe que as escolas primárias ensinem a arte de ler com incredulidade os jornais (...) Das pessoas que conheço, poucas chegam a soletrá-la (...) pensam que um fato aconteceu porque está impresso em grandes letras negras; confundem a verdade com o corpo 12 (...) Russell propõe que o Estado trate de imunizar os homens contra esses agouros e sofismas. Por exemplo, sugere que os alunos estudem as últimas derrotas de Napoleão através dos boletins do Moniteur, ostensivamente triunfais (Borges, 2007b: 150).

O segundo pacto, o ficcional, é baseado no que Lillian Furst (apud Lehman, 1998: 27) chama de adequatio do texto realista. A idéia que ocupa o lugar da "profundamente mimética alethéia", a adequatio é o senso de que a narrativa é uma ilusão autoconsciente, mas investida [invested] de verdade por meio da crença no poder da representação. Uma ficção que não é mentira. De acordo com Eco, “o leitor tem de saber que o que está sendo 
narrado é uma história imaginária, mas nem por isso deve pensar que o escritor está contando mentiras" (apud Resende, op. cit.: 101).

Este leitor que Resende delineia se faz presente como alteridade, como o outro que reconheço numa relação de construção do mundo. Com ele se negociaria o que é real. Diálogo. Mas Wolfe não concordaria com a "falsa oposição" entre verdade e ficção que Resende enxerga em sua produção. Diz Resende, na conclusão de Textuações, que esta oposição inviabiliza a noção de "palavra em dobra",

em que qualquer verdade se faz possível e na qual o que se quer ficcional deixa de ser ilusão para se perfazer do real. Portanto, relativizada e pluralizada, a verdade passa a ser constitutiva das manifestações discursivas como um todo, deixando de ser critério distintivo de um tipo de discurso (116, grifo nosso).

Suspeitamos que Wolfe - pelo menos o da entrevista a Bellamy - sentiria pruridos ante uma leitura tão aberta de sua escritura "objetiva".

\section{Referências Bibliográficas}

BARTHES, Roland. O rumor da língua. São Paulo: Martins Fontes, 2004.

BLOOM, Harold. A angústia da influência. São Paulo: Imago, 2002.

BORGES, Jorge Luis. Ficções. São Paulo: Companhia das Letras, 2007.

. Outras inquisições. São Paulo: Companhia das Letras, 2007 (b).

CANDIDO, Antonio (org.). A personagem de ficção. São Paulo: Perspectiva, 1987. (1 ${ }^{\mathrm{a}}$ edição: 1968)

DAWKINS, Richard. Deus, um delírio. São Paulo: Companhia das Letras, 2007.

DERRIDA, Jacques. A farmácia de Platão. São Paulo: Iluminuras, 2005.

ECO, Umberto. Lector in fabula. $2^{\text {a }}$ edição. São Paulo: Perspectiva, 2004. 
. Obra aberta. $9^{a}$ edição. São Paulo: Perspectiva, 2003. (1ª edição: 1967)

. Seis passeios pelos bosques da ficção. São Paulo: Cia. Das Letras, 1994.

. Sobre os espelhos e outros ensaios. $3^{\mathrm{a}}$ edição. Rio de Janeiro: Nova

Fronteira, 1989.

FERREIRA, Alvaro Emidio. Racionalismo crítico e Jornalismo: elementos para uma reflexão epistemológica. Dissertação de mestrado. São Paulo: ECA-USP, 2002.

FLUSSER, Vilém. Ficções filosóficas. São Paulo: Edusp, 1998. . Língua e realidade. São Paulo: Herder, 1963.

FRANKFURT, Harry. Sobre falar merda. Rio de Janeiro: Intrínseca, 2005.

LEHMAN, Daniel. Matters of fact: reading nonfiction over the edge. Athens, Ohio: Ohio University Press, 1998.

LIMA, Edvaldo Pereira. Páginas ampliadas. 2a edição. São Paulo: Manole, 2003.

MARCONDES FILHO, Ciro. O escavador de silêncios: formas de construir $e$ desconstruir sentidos na Comunicação. São Paulo: Paulus, 2004.

MATURANA, Humberto. Ontologia da realidade. Belo Horizonte: Ed. UFMG, 1997.

MINOIS, George. História do riso e do escárnio. São Paulo: UNESP, 2003.

MORIN, Edgar. O Método 3 (O Conhecimento do conhecimento). Porto Alegre: Sulina, 1999.

PIGLIA, Ricardo. O último leitor. São Paulo: Companhia das Letras, 2006. 
RESENDE, Fernando. Textuações: ficção e fato no Novo Jornalismo de Tom Wolfe. São Paulo: Annablume; FAPESP, 2002.

ROSENFELD. Anatol. Texto/contexto I. São Paulo: Perspectiva, 1996. (1 a edição: 1969)

TODOROV, Tzvetan. As estruturas narrativas. São Paulo: Perspectiva, 1977.

TUCHMAN, Gaye. Making news: a study in the construction of reality. New York: Free Press, 1980.

WOLFE, Tom. Radical chique e o Novo Jornalismo. São Paulo: Companhia das Letras, 2005.

Ilusionista, O. República Tcheca, EUA, 110 min., 2006. Dir.: Neil Burger.

Lisbela e o prisioneiro. Brasil, 106 min., 2003. Dir.: Guel Arraes. 